OPEN ACCESS

Edited by:

Geert Wiegertjes,

Wageningen University and Research,

Netherlands

Reviewed by:

Jialong Yang,

East China Normal University, China

Uwe Fischer,

Friedrich-Loeffler-Institute, Germany

${ }^{*}$ Correspondence:

Zhen Xu

zhenxu@mail.hzau.edu.cn

${ }^{\dagger}$ These authors have contributed equally to this work

Specialty section: This article was submitted to

Comparative Immunology,

a section of the journal

Frontiers in Immunology

Received: 15 July 2020

Accepted: 19 October 2020

Published: 16 November 2020

Citation:

Dong F, Yin G-m, Meng K-f, Xu H-y, Liu X, Wang Q-c and Xu Z (2020) IgT

Plays a Predominant Role in the Antibacterial Immunity of Rainbow

Trout Olfactory Organs.

Front. Immunol. 11:583740. doi: 10.3389/fimmu.2020.583740

\section{IgT Plays a Predominant Role in the Antibacterial Immunity of Rainbow Trout Olfactory Organs}

\author{
Fen Dong ${ }^{1 \dagger}$, Guang-mei Yin ${ }^{1 \dagger}$, Kai-feng Meng ${ }^{1}$, Hao-yue $\mathrm{Xu}^{1}$, Xia Liu ${ }^{1}$, Qing-chao Wang ${ }^{1}$ \\ and Zhen $X u^{1,2,3 *}$ \\ ${ }^{1}$ Department of Aquatic Animal Medicine, College of Fisheries, Huazhong Agricultural University, Wuhan, China, ${ }^{2}$ Laboratory \\ for Marine Biology and Biotechnology, Qingdao National Laboratory for Marine Science and Technology, Qingdao, China, \\ ${ }^{3}$ Key Laboratory of Marine Biotechnology of Fujian Province, Institute of Oceanology, Fujian Agriculture and Forestry \\ University, Fuzhou, China
}

The olfactory organs (OOs) of vertebrates play important roles in their extraordinary chemosensory capacity, a process during which they are continuously exposed to environmental pathogens. Nasopharynx-associated lymphoid tissue (NALT) contains B cells and immunoglobulins (Igs), which function as the first defense line against antigens in mammals and also exist in teleosts. However, the immune responses of teleost NALT B cells and Igs during bacterial infection remain largely uncharacterized. In this study, rainbow trout were infected with Flavobacterium columnare via continuous immersion, after which the adaptive immune responses within NALT were evaluated. F. columnare could invade trout nasal mucosa and cause histopathological changes in trout $\mathrm{O}$. Moreover, the accumulation of $\operatorname{lgT}^{+} \mathrm{B}$ cells in trout nasal mucosa was induced by bacterial challenge, which was accompanied by strong bacteria-specific IgT responses in the nasal mucus. Importantly, our study is the first to report local nasal-specific immune responses in teleosts during bacterial challenge by characterizing the local proliferation of $\lg \mathrm{T}^{+} \mathrm{B}$ cells and generation of bacteria-specific IgT in trout OOs after $F$. columnare infection. In addition to the strong IgT and $\lg ^{+} \mathrm{B}$ cells responses in $\mathrm{OO}$, bacteria-specific $\lg \mathrm{T}$ and $\operatorname{lgM}$ were also detected in serum following bacterial challenge. Taken together, our findings suggest that $\lg T$ functions as an important mucosal lg in teleost NALT and mediates local adaptive immunity during bacterial infection, which is similar to their protective role during parasitic infection.

Keywords: rainbow trout, immunoglobulins, B cells, nasopharynx-associated lymphoid tissue, bacterial infection

\section{INTRODUCTION}

The olfactory organs (OOs), which vertebrates rely on to identify substances in the environment, are continuously exposed to external microorganisms, and therefore a powerful defense system in their mucosal surface against infection is crucial (1). Particularly, teleost fish must actively draw water containing dissolved chemicals into their OOs to sense olfactory signals (2). At the same time, olfactory organs also experience continuous stimuli from the environments, which contain numerous toxins and pathogens. Therefore, a strong immune system is vital to protect the mucosal surface of OOs from pathogenic 
invasion. In birds and mammals, the nasopharynx-associated lymphoid tissue (NALT), which is composed of organized lymphoid tissue (O-NALT) (i.e., tonsils) and diffuse NALT (DNALT), is generally considered the first line of defense against antigens $(1,3)$. However, only D-NALT is present in most teleosts and shares the main features of other teleost mucosa-associated lymphoid tissues (MALTs) (4). Teleost D-NALT has been found to contain abundant myeloid cells, T cells, and B cells (4). Moreover, in mammals, long-term virus-specific immune responses have been reported in the D-NALT but not in the O-NALT following exposure to the influenza virus, suggesting that D-NALT may play a key role in nasal antibody-mediated immunity (5).

Teleost fish represent the most ancient bony vertebrates that possess immunoglobulins (Igs). Unlike mammals, which express five Ig isotypes, only three Ig classes have been identified in teleosts (i.e., IgM, IgD, and IgT/IgZ) (6). IgM is the prevalent Ig class in teleost plasma, which is mainly responsible for systemic immunity $(6,7)$. IgD is also an ancient Ig class that has been identified in most teleost fish (8) and secreted $\operatorname{IgD}(\mathrm{sIgD})$ coats a lower percentage of microbiota in fish mucosal surfaces when compared to IgT or IgM $(9,10)$, and its function still requires further characterization. Additionally, teleost IgT (also known as IgZ) was the third Ig class described in $2005(11,12)$, which was demonstrated to mainly function in mucosal immunity, analogous to mammalian IgA (7). Upon parasitic challenge, IgT/IgZ was the dedicated Ig isotype in mucosal immune tissues including the gut, gills, and OO, whereas IgM was mainly involved in systemic immune responses $(7,9,13)$. In mammals, bacteria-specific IgA is elevated for bacterial elimination in nasal mucus after pathogenic infection $(14,15)$, whereas the Ig-mediated adaptive immunity in the teleost $\mathrm{OO}$ during bacterial infection is not well understood. Given that teleost IgT shares a similar dedicated Ig role in mucosal tissues as mammalian IgA during parasitic infection (13), we hypothesized that $\operatorname{sgT}$ in the teleost NALT is also a dedicated Ig isotype that mediates adaptive immunity upon bacterial infection.

Flavobacterium columnare, the causative pathogen for columnaris disease in many fish species including common carp (Cyprinus carpio), rainbow trout (Oncorhynchus mykiss), yellow perch (Perca flavescens), and whitefish (Coregonus clupeaformis) (16-19) is known to cause severe mucosal tissue damage and high mortalities in infected fish $(19,20)$. However, the role of Igmediated adaptive immunity in fish NALT during bacterial infection remains unknown. In this study, we found that $F$. columnare could invade the trout $\mathrm{OO}$ to induce severe histological changes and IgT in nasal mucus played a central role against bacterial challenge. Moreover, we identified the local proliferation of $\operatorname{IgT}^{+} \mathrm{B}$ cells in nasal mucosa and bacteria-specific IgT responses in nasal mucus against bacterial infection for the first time in teleosts. Therefore, our results highlight the predominant role of $\operatorname{sIg} \mathrm{T}$ in teleost NALT against bacterial infection.

\section{MATERIALS AND METHODS}

\section{Fish Maintenance}

Rainbow trout (mean weight, 3-5 g) used in the study were obtained from Gerui fish farm in Shiyan (Hubei, China), and maintained in the aquarium tanks using a water recirculation system involving thermostatic temperature control and extensive biofiltration. Fish were acclimatized for at least 14 days at $16^{\circ} \mathrm{C}$ and fed daily with commercial trout pellets at a rate of $0.5 \%-1 \%$ body weight during the whole experiment period. The feeding was terminated at $48 \mathrm{~h}$ before sampling. For sampling, fish were anesthetized with MS-222 and blood was removed through the caudal vein to minimize the blood content in the collected organs. Animal procedures were approved by the Animal Experiment Committee of Huazhong Agricultural University.

\section{F. columnare Strain and Infection}

The bacteria used in this study was Flavobacterium columnare $\mathrm{G}_{4}$ strain, obtained from professor Pin Nie's lab in the Institute of hydrobiology, Chinese academy of sciences. F. columnare strain $\mathrm{G}_{4}$ was cultured in Shieh broth as described previously (21). Total 30 Fish ( 3-5 g) were immersed with $F$. columnare at a final concentration of $1 \times 10^{6} \mathrm{CFU} \mathrm{ml} l^{-1}$ for $4 \mathrm{~h}$ at $16^{\circ} \mathrm{C}$, and then transferred into the new aquarium. The olfactory organ samples were collected at $1,2,4,7,14,21,28$, and 75 days post infection (dpi). Moreover, fluids (serum and nasal mucus) were taken after 28 days, which was set as the infected group. For prolonged immune response analysis, fish were exposed to bacteria twice again at $30^{\text {th }}$ day and $60^{\text {th }}$ day after the first infection with the same bacterial dosage. Fish samples were taken two weeks after the last challenge, i.e. $75^{\text {th }}$ day post first infection, which was set as the survivor group. As a control (mock infected), the same number of fish were maintained in a similar tank with the same culture medium without bacteria. To explore the invasion route and tissue distribution of bacteria in trout $\mathrm{OO}$, we used the special GFP-expressing $F$. columnare $\mathrm{G}_{4}$ strain (green fluorescent protein (GFP)-labeled mutant which is stable inheritance and expression) to infect rainbow trout via immersion method as above. The olfactory organ samples were collected at 1,2,3, 4 , and 7 dpi.

\section{Histology, Light Microscopy, and Immunofluorescence Microscopy Studies}

The olfactory organ from the control trout and infected trout were dissected and fixed with $4 \%$ neutral buffered formalin at $4^{\circ} \mathrm{C}$ overnight, then embedded in paraffin, and $5 \mu \mathrm{m}$ thick sections for hematoxylin and eosin ( $\mathrm{H} \& \mathrm{E})$ or Alcian blue $(\mathrm{A} \& \mathrm{~B})$ staining as reported previously (13). Images were acquired in a microscope (Olympus) using the Axiovision software.

To detect the localization of F. columnare in trout olfactory organ, we used GFP-expressing F. columnare for infection. All the sections were stained with DAPI (4, 6-diamidino-2phenylindole; $1 \mu \mathrm{g} \mathrm{ml}{ }^{-1}$; Invitrogen). In order to detect the $\operatorname{IgT}^{+}$and $\operatorname{IgM}^{+}$B-cells, polyclonal rabbit anti-trout $\operatorname{IgT}(\mathrm{pAb} ; 0.5$ $\mu \mathrm{g} \mathrm{ml}^{-1}$ ) and monoclonal mouse anti-trout IgM (IgG1 isotype; 1 $\mu \mathrm{g} \mathrm{ml}^{-1}$ ) (7) were used to incubate sections at $4^{\circ} \mathrm{C}$ overnight. After washing three times with PBS, secondary antibodies Alexa Fluor 488-conjugated AffiniPure Goat Anti-Rabbit IgG $(\mathrm{H}+\mathrm{L})$ and Cy3-conjugated AffiniPure Goat Anti-Mouse IgG $(\mathrm{H}+\mathrm{L})$ $\left(2.5 \mu \mathrm{g} \mathrm{ml}^{-1}\right.$ each; Jackson ImmunoResearch Laboratories Inc.) were added and incubated for $40 \mathrm{~min}$ at room temperature. Then after washing three times with PBS, sections were stained with 
DAPI (4', 6-diamidino-2 phenylindole; $1 \mu \mathrm{g} \mathrm{ml}^{-1}$; Invitrogen) for $8 \mathrm{~min}$. All the sections were mounted with antifade mounting medium (Beyotime). Images were acquired and analyzed using an Olympus BX53 fluorescence microscope (Olympus) and the iVision-Mac scientific imaging processing software (Olympus).

\section{RNA Isolation and Quantitative Real-Time PCR Analysis}

Total RNA was isolated using the TRIZol reagent according to the manufacturer's instructions. All the samples for quantitative real-time PCR (qPCR) analyses were homogenized by TissueLyser II (Jingxin Technology) with steel beads at shaking ( $60 \mathrm{~Hz}$ for $1 \mathrm{~min}$ ) following the manufacturer's instructions. The concentrations of the isolated RNA were carried out by NanoDropND-1000 spectrophotometer (Thermo Scientific), and the integrity of tissue RNA was determined by agarose gel electrophoresis. To normalize gene expression levels, equivalent amounts of the total RNA $(1 \mu \mathrm{g})$ from each sample was used for cDNA synthesis. The cDNA synthesis was performed the SuperScript first-strand synthesis system (Yeasen) in a $20 \mu \mathrm{l}$ reaction volume. The qPCRs were performed on a $7500 \mathrm{qPCR}$ system (Applied Biosystems) using the $2 \times$ SYBR Green qPCR Master mix (Yeasen). The synthesized cDNA was diluted 4 times and then used as a template for qPCR analysis. All samples were performed the following conditions: $95^{\circ} \mathrm{C}$ for $5 \mathrm{~min}$, followed by 40 cycles at $95{ }^{\circ} \mathrm{C}$ for $10 \mathrm{~s}$ and at $58^{\circ} \mathrm{C}$ for $30 \mathrm{~s}$. A dissociation protocol was carried out after thermos cycling to confirm that a single band of the correct size was amplified. Ct values determined for each sample were normalized against the values for trout housekeeping gene $(\mathrm{EF} 1 \alpha)$. The gene expression levels were shown as $2^{-\Delta \Delta \mathrm{Ct}}$ using the Pfaffl's method (22). Primer sequences (species-specific 16S rRNA primers were used for $F$. columnare) can be found in Table $\mathbf{1}$.

\section{DNA Extraction and PCR Amplification}

To detect $F$. columnare in trout nasal after infection, the homogenates of olfactory organ in the control fish and infected fish were cultured in the plate, using steel beads and shaking ( $60 \mathrm{~Hz}$ for $1 \mathrm{~min}$ ) following the manufacturer's instructions. One day later, the bacteria in the plate of infected fish were collected, and those colonies present rhizoid and flat with yellow center were then diluted in the Shieh broth for 24 h culture at $28^{\circ} \mathrm{C}$. PCR reactions were performed in triplicate $20 \mu \mathrm{l}$ mixtures containing $4 \mu \mathrm{l}$ of $5 \times$ FastPfu Buffer, $2 \mu \mathrm{l}$ of $2.5 \mathrm{mM}$ dNTPs, $0.8 \mu \mathrm{l}$ of each primer $(5 \mu \mathrm{M})\left(\mathrm{F} 1: 5{ }^{\prime}\right.$-GCCCAGAGAAATTTGGAT3' R1: 5'TGCGATTACTAGCGAATCC -3') (23), $0.4 \mu$ l of FastPfu Polymerase and $12 \mu \mathrm{l}$ bacteria solution. The PCR reactions were conducted using the following program: $3 \mathrm{~min}$ of denaturation at $95^{\circ} \mathrm{C}, 27$ cycles of $30 \mathrm{~s}$ at $95^{\circ} \mathrm{C}, 30 \mathrm{~s}$ for annealing at $55^{\circ} \mathrm{C}$, and $45 \mathrm{~s}$ for elongation at $72^{\circ} \mathrm{C}$, and a final extension at $72^{\circ} \mathrm{C}$ for $10 \mathrm{~min}$. Agarose gels were used to exhibit the PCR products and image was acquired from the ChemiDoc TM XRS+ imaging system (Bio-Rad).

\section{Collection of Serum and Nasal Mucus}

Before sampling, trout were anesthetized with MS-222, and serum was collected and stored as previously described (7). The nasal mucus samples were collected using the method described
TABLE 1 | Primers used in this study.

\begin{tabular}{|c|c|c|c|}
\hline Gene & $\begin{array}{l}\text { Primer } \\
\text { name }\end{array}$ & Primer sequence $\left(5^{\prime}-3\right)$ & $\begin{array}{c}\text { GenBankAccession } \\
\text { no. }\end{array}$ \\
\hline \multirow{2}{*}{$\begin{array}{l}16 S \\
\text { rRNA }\end{array}$} & Fc16F & GAGTGGCTAAGCGAAAGTGAT & EU395796.1 \\
\hline & Fc16R & ACCTGACACCTCACGGCAC & \\
\hline \multirow[t]{2}{*}{ C1R } & C1RF & GCCGACTGCTACTACGA & NM_001124380.1 \\
\hline & C1RR & GGTGCCTATGTGCTCTATG & \\
\hline \multirow[t]{2}{*}{ IL-8 } & $\mathrm{IL}-8 \mathrm{~F}$ & TGTCGTTGTGCTCCTGG & NM_001124362.1 \\
\hline & $\mathrm{IL}-8 \mathrm{R}$ & CCTGACCGCTCTTGCTC & \\
\hline \multirow[t]{2}{*}{ TNF- $\alpha$} & TNF- $\alpha F$ & AACCGAAAGTGCGAGTG & XM_021565683.1 \\
\hline & TNF- $\alpha R$ & TGGTGCGATCTGGAGTA & \\
\hline \multirow[t]{2}{*}{ HSPA1s } & HSPA1sF & GATGGACAAGGCTCAGGT & XM_021567143.1 \\
\hline & HSPA1sR & CGTCAAGGAGGAGAAGGT & \\
\hline \multirow[t]{2}{*}{ NOS2 } & NOS2F & GGCAGTCAAGAACCAACC & XM_021581479.1 \\
\hline & NOS2R & GAGCACCAAACGCTAATT & \\
\hline \multirow[t]{2}{*}{$\lg \mathrm{D}$} & $\operatorname{lgDF}$ & CAGGAGGAAAGTTCGGCATCA & AY748802.1 \\
\hline & $\operatorname{lgDR}$ & СCTCAAGGAGCTCTGGTITGGA & \\
\hline \multirow[t]{2}{*}{ IL-10 } & IL-10F & CACCGCCTTCTCCACCATC & NM_001245099.1 \\
\hline & IL-10R & CCATAGCGTGACACCCCAC & \\
\hline \multirow[t]{2}{*}{ CATH-1 } & CATH-1F & CTGGAGGCAAGCAACAAC & NM_001124480.1 \\
\hline & CATH-1R & CCCCCAAGACGAGAGACA & \\
\hline \multirow[t]{2}{*}{$\lg M$} & $\operatorname{lgM} F$ & AAGAAAGCCTACAAGAGGGAGA & S63348.1 \\
\hline & $\lg M R$ & CGTCAACAAGCCAAGCCACTA & \\
\hline \multirow[t]{2}{*}{$\lg T$} & $\operatorname{lgTF}$ & CAGACAACAGCACCTCACCTA & AY870264 \\
\hline & $\lg T R$ & GAGTCAATAAGAAGACACAACGA & \\
\hline \multirow[t]{2}{*}{ IRF4 } & IRF4F & CGCCCTACGGAGATAAAC & XM_021604510.1 \\
\hline & IRF4R & TCAGCAGCACCTGGAGAC & \\
\hline \multirow[t]{2}{*}{ CXCL10 } & CXCL10F & ACATCAACGGTCCTCATC & XM_021622222.1 \\
\hline & CXCL10R & АСАСТTСТТСССТТСТСС & \\
\hline \multirow[t]{2}{*}{ C3 } & C3F & CСTCACAACAAGAGTGCACATC & XM_021561577.1 \\
\hline & C3R & CCAAGTGGGCAAACTCATCTCC & \\
\hline \multirow[t]{2}{*}{ SAA } & SAAF & TTGTTCTGACCCTCGTTG & XM_021607573.1 \\
\hline & SAAR & CCTGGCAGCATCATAGTT & \\
\hline \multirow[t]{2}{*}{ plgR } & plgRF & GTACAGCAGGTGTTCACAGTAAC & FJ940682.1 \\
\hline & plgRR & CCACAGACAGACCTTGGATAAC & \\
\hline \multirow[t]{2}{*}{$\mathrm{EF} 1 \alpha$} & $\mathrm{EF} 1 \alpha \mathrm{F}$ & CAACGATATCCGTCGTGGCA & NM_001124339.1 \\
\hline & $\mathrm{EF} 1 \alpha \mathrm{R}$ & ACAGCGAAACGACCAAGAGG & \\
\hline
\end{tabular}

previously (13). Briefly, trout olfactory organ was collected (together with bones surrounding the nasal cavity) and then washed three times with PBS on a shaker (each time $10 \mathrm{~min}$ ) to remove the remaining blood in the tissue and the mucus in the tissue's surface. The nasal cavity was exposed via cut with scissors and was incubated for $12 \mathrm{~h}$ at $4^{\circ} \mathrm{C}$, with slightly shaking in protease inhibitor buffer $(1 \times \mathrm{PBS}$, containing $1 \times$ protease inhibitor cocktail [Roche], $1 \mathrm{mM}$ phenylmethylsulfony fluoride [Sigma]; $\mathrm{pH}$ 7.2) at a ratio of $100 \mathrm{mg}$ of the tissue per $\mathrm{ml}$ of buffer. The suspension (nasal mucus) was collected into $1.5 \mathrm{ml}$ centrifuge tube, and then vigorously vortexed and centrifuged at $400 \mathrm{~g}$ for $10 \mathrm{~min}$ at $4^{\circ} \mathrm{C}$ to remove trout cells. The cell-free supernatant was thereafter centrifuged at $10,000 \mathrm{~g}$ for $10 \mathrm{~min}$ at $4^{\circ} \mathrm{C}$ to remove the nasal bacteria from mucus. Finally, the resulting supernatant (containing nasal mucus) was harvested, filtered with a $0.45 \mu \mathrm{m}$ syringe filter (Millipore) and stored at $4^{\circ} \mathrm{C}$ prior to use the same day.

\section{SDS-PAGE and Western Blot}

Nasal mucus and serum samples were resolved on 4\%-15\% SDSPAGE Ready Gel (Bio-Rad) under non-reducing conditions as described previously $(9,13)$. For western blot analysis, the proteins on the gels were transferred onto PVDF membranes 
(Bio-Rad). Then, the membranes were blocked with $8 \%$ skim milk and incubated with anti-trout IgT (rabbit polyclonal antibody, pAb), anti-trout IgM (mouse monoclonal antibody, $\mathrm{mAb}$ ) or biotinylated anti-trout $\operatorname{IgD}$ (mouse mAb) (9) antibodies followed by incubating with peroxidase-conjugated anti-rabbit, anti-mouse IgG (Invitrogen) or streptavidin (Invitrogen). For quantitative analyses of $\operatorname{IgT}, \operatorname{IgM}$, and $\operatorname{IgD}$ in nasal mucus and serum, immunoreactivity bands were first visualized with an enhanced chemiluminescent reagent (Advansta) and scanned by Amersham Imager 600 Imaging System (GE Healthcare), then band densitometry was analyzed with ImageQuant TL software (GE Healthcare). Finally, the concentrations of IgT, IgM, and IgD were determined by plotting the obtained signal strength values on a standard curve generated for each blot using known amounts of purified trout IgT, IgM, or IgD.

\section{Proliferation of B Cells in the Olfactory Organ of Trout}

The proliferation of $\mathrm{B}$ cells was assayed using the revised methodology as previously reported $(9,13,24)$. Briefly, both the control fish and survivor fish ( $15 \mathrm{~g})$ were anesthetized with MS222 and intravenously injected with $200 \mu \mathrm{g}$ 5-ethynyl-2'deoxyuridine (EdU) (Invitrogen), and $24 \mathrm{~h}$ later, the olfactory organ from control and survival fish were dissected, fixed in $4 \%$ neutral buffered formalin as described above. Paraffin sections were incubated with polyclonal rabbit anti-trout $\operatorname{IgT}\left(\mathrm{pAb} ; 0.5 \mu \mathrm{g} \mathrm{ml}{ }^{-1}\right.$ ) and monoclonal mouse anti-trout $\operatorname{IgM}$ (IgG1 isotype; $1 \mu \mathrm{g} \mathrm{ml}^{-1}$ ) at $4^{\circ} \mathrm{C}$ overnight. After washing three times with PBS, sections were incubated with Alexa Fluor 488-conjugated AffiniPure Goat antirabbit IgG and Cy3-conjugated AffiniPure Goat anti-mouse IgG (2.5 $\mu \mathrm{g} \mathrm{ml}^{-1}$ each; Jackson ImmunoResearch Laboratories Inc.) for $45 \mathrm{~min}$ at room temperature. For the detection of $\mathrm{EDU}^{+}$cells, we used the kit according to the manufacturer's instructions (Click-iT EdU Alexa Fluor 647 Imaging Kit, Invitrogen). The nuclei were stained with DAPI (4', 6-diamidino-2 phenylindole; $1 \mu \mathrm{g} \mathrm{ml}{ }^{-1}$ : Invitrogen) for $8 \mathrm{~min}$. Images were acquired and analyzed using an Olympus BX53 fluorescence microscope (Olympus) and the iVision-Mac scientific imaging processing software (Olympus). The percentage of $\mathrm{EdU}^{+} \mathrm{Ig}^{+}$positive cells means the ratio of $\mathrm{EdU}^{+} \mathrm{Ig}^{+}$cells to $\mathrm{Ig}^{+}$cells. The percentage of $\mathrm{EdU}^{+}$cells means the ratio of $\mathrm{EdU}^{+}$cells to trout $\mathrm{OO}$ cells.

\section{Tissue Explants Culture}

The culture of trout olfactory organ explants was conducted using the similar method as previously described $(9,13)$. Briefly, both control and survivor fish were sacrificed with an overdose of MS222 , and blood was removed through the caudal vein to minimize the blood content in the collected organs. Thereafter, olfactory organ (approximately $20 \mathrm{mg}$ of each tissue) was submerged in 70\% ethanol for $30 \mathrm{~s}$ to eliminate possible bacteria on their surface and then washed twice with PBS. Finally, tissues were placed in a 24-well plate and cultured with $120 \mu \mathrm{l}$ DMEM medium (Invitrogen), supplemented with $10 \% \mathrm{FBS}, 100 \mathrm{U} \mathrm{ml}^{-1}$ penicillin, $100 \mu \mathrm{g} \mathrm{ml}^{-1}$ streptomycin, $200 \mu \mathrm{g} \mathrm{ml} l^{-1}$ amphotericin B and $250 \mu \mathrm{g} \mathrm{ml}^{-1}$ gentamycin sulfate, with $5 \% \mathrm{CO} 2$ at $17^{\circ} \mathrm{C}$. After 7 days culture, the supernatants were harvested, centrifuged and stored at $4^{\circ} \mathrm{C}$ prior to use the same day, otherwise, stored at $-80^{\circ} \mathrm{C}$ until further analysis.

\section{Binding of Trout Immunoglobulins to F. columnare}

To access whether the infected fish and survivor fish generated $\mathrm{F}$. columnare-specific immunoglobulins, the capacity of $\operatorname{IgT}, \operatorname{IgM}$ and IgD from serum, nasal mucus or tissue of olfactory organ explants supernatants binding to F. columnare was assayed using a pull-down assay as described previously $(9,13)$. Briefly, the $F$. columnare suspensions $\left(1 \times 108 \mathrm{CFU} \mathrm{ml} \mathrm{m}^{-1}\right)$ were pre-incubated with a solution of $0.5 \%$ BSA in PBS $\left(\mathrm{pH} \mathrm{7.2)}\right.$ at $4^{\circ} \mathrm{C}$ for $2 \mathrm{~h}$. Thereafter, $F$. columnare $(40 \mu \mathrm{l})$ suspensions were incubated with diluted nasal mucus, serum or tissue of olfactory organ explants supernatants from the infected fish, survivor fish or control fish at $4^{\circ} \mathrm{C}$ for $4 \mathrm{~h}$ with continuous shaking in a $300 \mu \mathrm{l}$ volume with $\mathrm{PBS}$ containing $1 \% \mathrm{BSA}$ ( $\mathrm{pH}$ 7.2). After incubation, the bacteria were washed three times with PBS, and bound proteins were eluted with $2 \times$ Laemmli Sample Buffer (Bio- Rad) and boiled for $5 \mathrm{~min}$ at $95^{\circ} \mathrm{C}$. The eluted material was resolved on 4-15\% SDS-PAGE Ready Gel (Bio-Rad) under non-reducing conditions, then the presence of $\operatorname{Ig} \mathrm{T}$, $\operatorname{IgM}$ or $\operatorname{IgD}$ was detected by western blotting using the anti-trout IgT, IgM, or IgD antibody as described above.

\section{Statistics}

An unpaired Student's t-test and one-way ANOVA with Bonferroni correction (Prism version 6.01; GraphPad) were used for analysis of differences between two groups or among three or more groups, respectively. Data were expressed as mean \pm SEM. All statistical significance in this study was set at $P<0.05$.

\section{RESULTS}

\section{Detection of $F$. columnare in Trout 00 After Infection}

Obvious clinical signs of columnaris disease (e.g., frayed fins and necrotic skin lesions) were detected in F. columnare-infected rainbow trout (Supplementary Figure 1A). After incubating OO tissue homogenates in Shieh agar plates, yellow-pigmented rhizoid colonies (i.e., resembling $F$. columnare colonies) could be observed in cultures containing infected fish homogenates, whereas no such colonies were observed in control fish homogenate cultures (Figure 1A). Moreover, PCR cloning of three different bacterial colonies that present typical $F$. columnare characteristics exhibited bands that were similar to that of the positive control (Supplementary Figure 1B). To further explore the invasion route and tissue distribution of bacteria in trout $\mathrm{OO}$, one special GFP-expressing F. columnare $\mathrm{G}_{4}$ strain was used to infect rainbow trout via immersion. Trout OO lamellae were found to harbor numerous green fluorescent bacteria at 1, 3, and 4 days post-infection (dpi) (Figure 1B). Quantitative real-time PCR (qPCR) analysis also confirmed the expression of $F$. columnare $16 \mathrm{~S}$ rRNA in trout $\mathrm{OO}$ after bacterial infection (Figure 1C). 


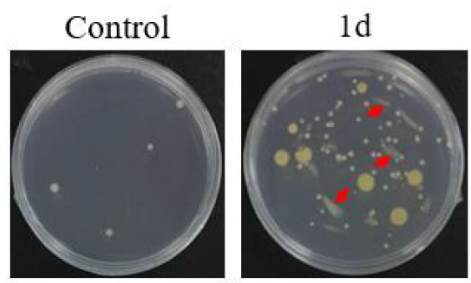

F.columnare

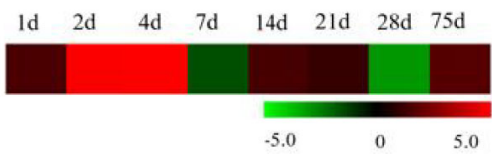

B
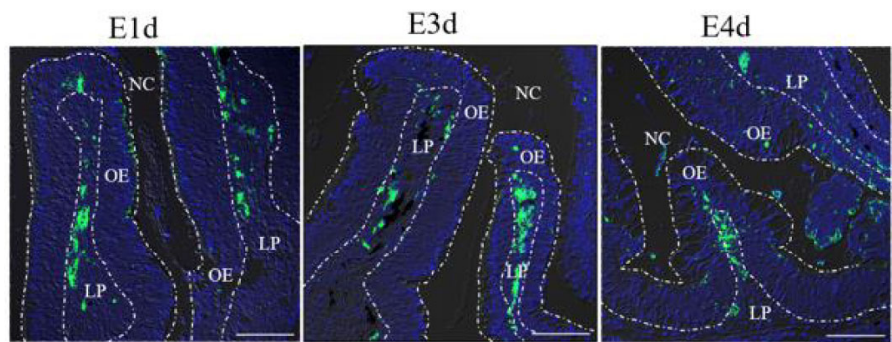

FIGURE 1 | Infection with $F$. columnare in rainbow trout. (A) The culture plates of olfactory organ from control fish (left) and 1 day infected fish (right). (B) localzation of $F$. cloumnare in olfactory organ of control fish and infected fish at 1, 3, and 4 dpi. Data are representative of three independent experiments. (C) Heat map demonstrated quantitative real-time PCR (qPCR) results of $F$. columnare in olfactory organ of infected fish versus control fish measured at 1, 2, 4, 7, 14, 21, 28, and 75 dpi ( $n=6$ fish per group). NC, nasal cavity; OE, olfactory epithelium; LP, lamina propria. Scale bar, $100 \mu \mathrm{m}$.

\section{Bacterial Infection Elicits Histopathological Changes and Immune Responses in Trout 00}

In addition to $F$. columnare detection, our study sought to characterize the associated morphological changes and immune-related gene expression in trout OO. Hematoxylin and eosin (H\&E) staining showed a significant enlargement of the lamina propria (LP) at the tip of the nasal lamella $(\sim 100 \mu \mathrm{m}$ away from the apex) in the infected fish when compared with that in the control fish (Figures 2A, B). A\&B staining also demonstrated that the number of goblet cells on the nasal lamella increased significantly upon infection (Figures 2C, D). Moreover, the mRNA expressions of immune-related genes in trout $\mathrm{OO}$ were significantly up-regulated as early as $1 \mathrm{dpi}$ (HSPA1s, NOS2, and IL-10) or 2 dpi (CATH-1 and IL-10) and reached their peak levels at $7 \mathrm{dpi}$ (Figure 2E). Moreover, the transcriptional levels of $\operatorname{IgT}$, IgM, and $\operatorname{IgD}$ were significantly increased at $2 \mathrm{dpi}$ and reached their peak at $28 \mathrm{dpi}$ (IgD) and 75 dpi (IgT and IgM) (Figure 2F).

\section{Bacterial Infection Elicits B Cell- and Igs- Mediated Adaptive Immune Response in Trout $\mathrm{OO}$}

Immunofluorescence analysis was used to detect the abundance of $\mathrm{IgT}^{+}$and $\operatorname{IgM}^{+} \mathrm{B}$ cells in trout $\mathrm{OO}$ to demonstrate the role of $\mathrm{B}$ cells in the adaptive immune response in trout $\mathrm{OO}$ during F. columnare infection. Few $\operatorname{IgT}^{+}$and $\operatorname{IgM}^{+}$B cells were detected in both the olfactory epithelium and the lamina propria of control fish (Figure 3A; isotype-matched control antibodies, Supplementary Figure 2), whereas a moderate increase in $\operatorname{IgT}^{+} \mathrm{B}$ cells was observed in the trout $\mathrm{OO}$ at $28 \mathrm{dpi}$ (Figure 3B). Moreover, the number of $\operatorname{IgT}^{+}$ $\mathrm{B}$ cells was dramatically higher in surviving fish at 75 dpi compared to the controls (Figure 3C). Similarly, the number of $\operatorname{IgM}^{+} \mathrm{B}$ cells in the trout $\mathrm{OO}$ did not significantly change in the infected fish (28 dpi) but significantly increased in surviving fish (75 dpi) compared to the controls (Figures 3A-C). The number of $\mathrm{IgT}^{+} \mathrm{B}$ cells increased significantly by $\sim 3$ fold and $\sim 6$ fold in the OOs of infected and surviving fish, respectively, whereas the number of $\operatorname{IgM}^{+} \mathrm{B}$ cells increased $\sim 3$ fold in the surviving fish (Figure 3D). Moreover, western blotting analyses demonstrated that IgT concentration in the nasal mucus of the infected and surviving fish increased by $\sim 35$ and $\sim 15$-fold of that in the control fish, respectively (Figure 3E). Notably, 15- fold and 3- fold increases of IgM concentrations were detected in the nasal mucus of infected and surviving fish, respectively, whereas $\operatorname{IgD}$ concentrations in the nasal mucus of the infected and survivor groups increased by $\sim 6$-fold and $\sim 3$-fold, respectively (Figure 3E). The serum concentrations of IgM and IgT increased in both the infected ( 2 and $\sim 3$-fold, respectively) and surviving fish ( $\sim 4$ and $\sim 3$-fold, respectively) (Figure 3F), whereas serum IgD concentrations did not significantly change in either the infected or surviving fish (Figure 3F). Pull-down assays were then conducted to detect bacteria-specific Igs in nasal mucus following $F$. columnare infection (Figure 4). The results demonstrated that bacteria-specific IgT binding could be detected in up to $1 / 100$ nasal mucus dilutions in both the infected and surviving fish, representing a $\sim 3.5$-fold and $\sim 2.7$-fold increase compared to the control, respectively (Figures $4 \mathrm{~A}-\mathrm{C}$ ). Bacteria-specific IgM binding 

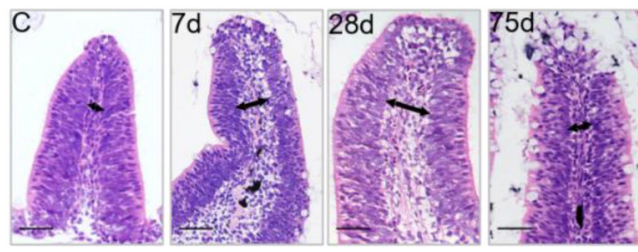

C

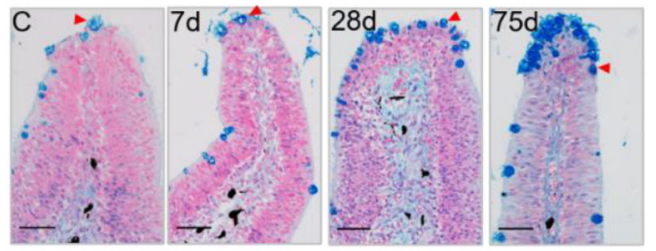

E

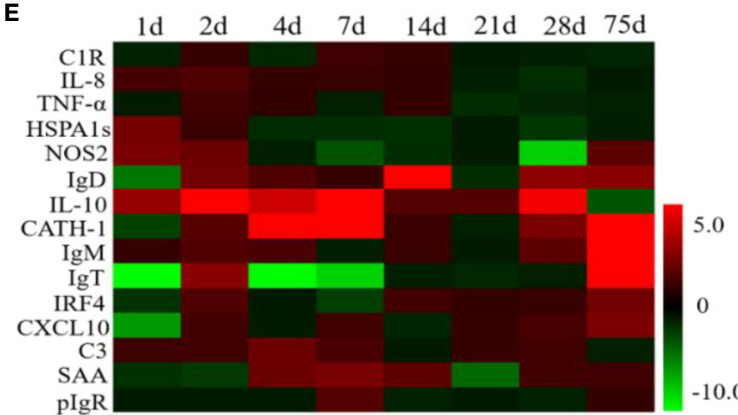

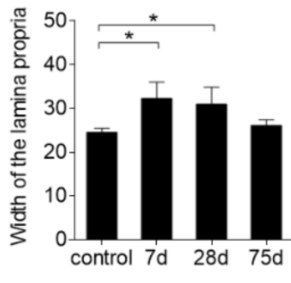

D
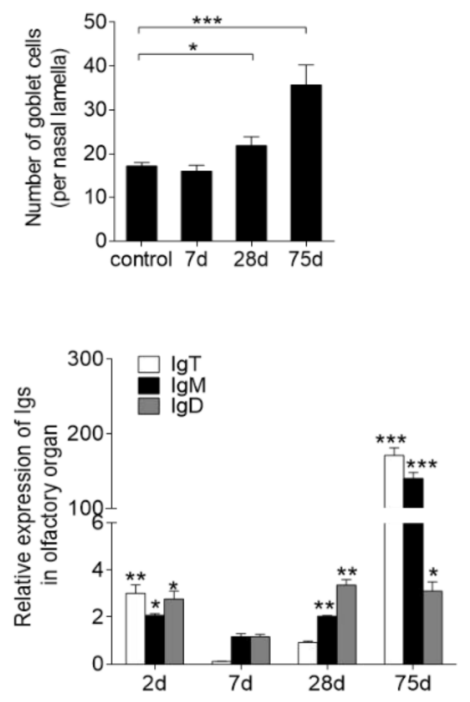

FIGURE 2 | Pathological changes and kinetics of the immune responses in the olfactory organ of trout infected with $F$. columnare. (A) Histological examination by $\mathrm{H} \& \mathrm{E}$ staining of olfactory organ from uninfected fish and $F$. columnare-infected rainbow trout at 7, 28 and 75 dpi. Black arrows indicate the width of LP at the tip region (100 $\mu \mathrm{m}$ from the lamellar tip) of the olfactory lamella. (B) The width of $L P$ at the tip region the olfactory lamella in control fish and $F$. columnare -infected rainbow trout at 7, 28, 75 dpi counted from A. (C) Histological examination by A \& B staining of olfactory organ from uninfected fish and $F$. columnare-infected rainbow trout at 7, 28 and 75 dpi. Red arrowheads indicate goblet cells. (D) The number of goblet cells at the olfactory lamella in control fish and $F$. columnare -infected rainbow trout at 7, 28 and 75 dpi counted from C. (E) Heat map illustrates quantitative real-time PCR results of relative mRNA levels for selected immune markers in F. columnare-infected fish versus control fish measured at 1, 2, 4, 7, 14, 21, 28 and 75 dpi ( $n=6$ per group) in the olfactory organ of rainbow trout. Data are expressed as mean fold increase in expression. (F) The expression levels of $\operatorname{lgM}$, $\lg D$ and $\lg T$ at 2, 7, 28 and 75 dpi with $F$. columnare in olfactory organ of rainbow trout. ( $n=6$ fish per group). LP: lamina propria. Scale bars, $50 \mu \mathrm{m}$. ${ }^{\star} p<0.05,{ }^{* \star} p<0.01,{ }^{* \star} p<0.001$ (one-way ANOVA with Bonferroni correction). Data are representative of three independent experiments (mean \pm SEM).

in serum could be detected in up to $1 / 10$ and 1/100 dilutions in the infected and surviving fish, which were $\sim 2$-fold and $\sim 7.7$ - fold higher than the control fish, respectively (Figures 4D-F). Similarly, bacteria-specific IgT binding could be detected in up to 1/100 serum dilutions of surviving fish, which represented a $\sim 2.3$-fold increase compared to the control fish but was still much lower than the bacteria-specific IgM (Figure 4F). No significant changes in the IgD titers in the nasal mucus or serum in infected and surviving fish were identified (Figure 4). These results suggested that Igs play an important role in adaptive immune responses in the trout $\mathrm{OO}$ upon F. columnare infection.

\section{Bacterial Infection Elicits Local Proliferation of B-Cells and Ig Responses in Trout $\mathbf{O O}$}

To investigate whether the increases in $\mathrm{IgT}^{+} \mathrm{B}$ cells in the $\mathrm{OO}$ of surviving fish resulted from local proliferation, the in vivo proliferative responses of $\operatorname{IgT}^{+}$and $\operatorname{IgM}^{+} \mathrm{B}$ cells were evaluated by staining with 5 -Ethynyl-2'-deoxyuridine (EdU), a thymidine analog that incorporates to DNA during cell division (25). Immunofluorescence microscopy analysis indicated that the percentage of proliferating cells in the $\mathrm{OO}$ of surviving fish $(\sim 7.22 \pm 0.63 \%)$ significantly increased compared to the control fish $(\sim 4.07 \pm 0.95 \%)$ (Figures 5A-C). Moreover, the percentage of $\mathrm{EdU}^{+} \mathrm{IgT}^{+} \mathrm{B}$ cells also increased significantly in the surviving fish $(\sim 17.32 \pm 1.63 \%)$ compared to the controls $(\sim 2.62 \pm 1.26 \%)$ (Figures 5A, B, D), whereas no significant changes were found in the percentage of $\mathrm{EdU}^{+} \mathrm{IgM}^{+} \mathrm{B}$ cells in trout $\mathrm{OO}$ between the control and surviving fish (Figures 5A, B, D). Bacteria-specific Igs titers were further measured in media containing cultured olfactory organs from the control and surviving fish (Figure 6). Bacteria-specific IgT binding could be detected in 1/100 diluted medium $(\sim 12$-fold) containing cultured OO explants from the surviving fish, whereas much lower bacteria-specific IgM titers were detected in the same medium (Figure 6). Moreover, negligible bacteria-specific IgD titers were detected in the cultured olfactory organ media from either the control or surviving fish (Figure 6). 
A

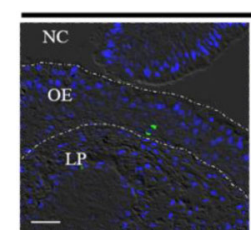

B

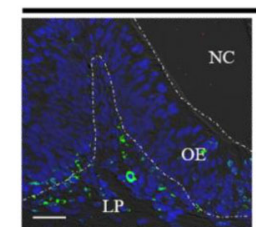

C

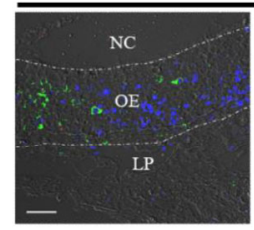

Control

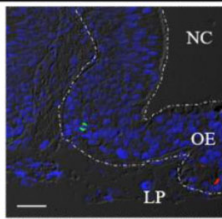

Infected

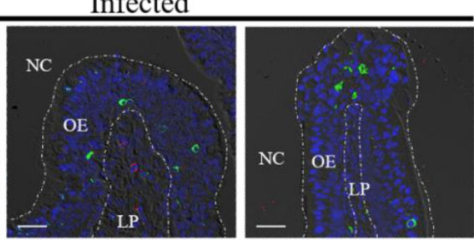

Survivor

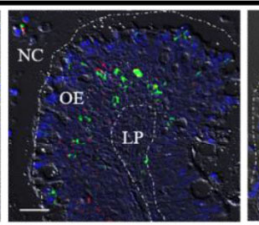

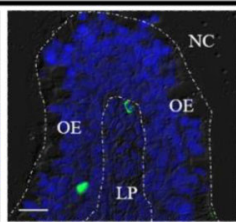

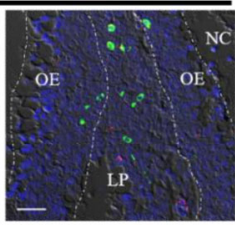

IgT IgM Nuclei
D

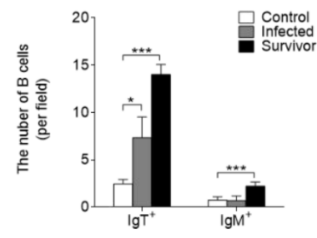

E
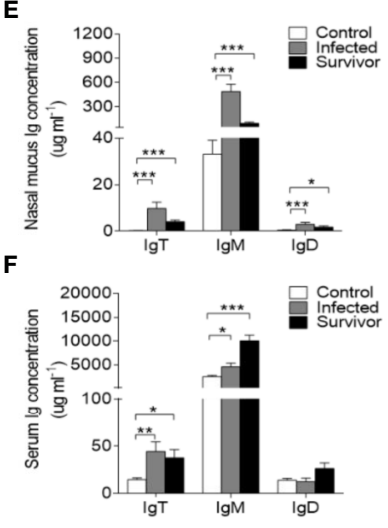

FIGURE 3 | Responses of $\operatorname{lgT}^{+} \mathrm{B}$ cells and lgs in the olfactory organ of trout infected with $F$. columnare. (A-C) Differential interference contrast images of immunefluorescence staining on paraffinic sections of olfactory organ from control fish (A), infected fish (28 dpi, B) and survivor fish $\left(75 \mathrm{dpi}\right.$, C). IgT $\mathrm{T}^{+}$and $\operatorname{lgM} \mathrm{M}^{+} \mathrm{B}$ cells were stained with rabbit anti-trout IgT (green) and mouse anti-trout IgM (red), respectively; nuclei were stained with DAPI (blue) (isotype-matched control antibody staining, Supplemental Figure 2). (D) The number of $\lg ^{+}$and $\operatorname{lgM}^{+}$B cells in paraffinic sections of olfactory organ from control fish, infected fish (28 dpi), and survivor fish (75 dpi) ( $n=6$ fish per group). (E, F) Concentration of IgT, IgM, and IgD in nasal mucus (E) and serum (F) of control, infected (28 dpi), and survivor fish (75 dpi) ( $n=12$ per group). NC, nasal cavity; OE, olfactory epithelium; LP, lamina propria. Scale bar, $20 \mu \mathrm{m} .{ }^{*} p<0.05,{ }^{* *} p<0.01,{ }^{* \star *} p<0.001$ (one-way ANOVA with Bonferroni correction). Data in (D-F) are representative of at least three independent experiments (mean \pm SEM).

\section{DISCUSSION}

In mammals, NALT is considered within the first line of immune defense against inhaled antigens, a process during which IgA plays a central role $(1,5)$. Teleost fish represent the most ancient bony vertebrates with NALT and are known to express three Ig classes $(4,6)$, which mediate the immune defense mechanisms in the $\mathrm{OO}$ (4). However, very little is known about the role of Igs in nasal immune defense against bacterial pathogens. Therefore, our study explored the immune responses of Igs and B cells in teleost OO against a bacterial pathogen and identified $\operatorname{IgT}$ as the predominant Ig isotype in teleost NALT during antibacterial immunity.

Columnaris disease, which is caused by F. columnare, is known to induce histological lesions in multiple mucosal tissues of fish including rainbow trout (18). Here, GFP-expressing F. columnare was observed in the trout $\mathrm{OO}$ at $1 \mathrm{dpi}$, particularly in the lamina propria (LP), and typical clinical signs (e.g., frayed fins and necrotic skin lesions) were also observed in infected trout. Alcian blue is a cationic dye used to stain acidic polysaccharides, including bacterial capsules. At a pH of 2.5, this dye stains both sulfated (sulfomucins) and carboxylated (sialomucins) mucopolysaccharides, which are found in the goblet cells located in the intestine. Moreover, we found that GFP-expressing F. columnare were mainly located in the lamina propria of the trout $\mathrm{OO}$ after challenge. Alcian blue was then used to detect goblet cells in the trout $\mathrm{OO}$ and only the cells located in the trout nasal epidermal layer were counted. Histological analyses indicated that the microscopic structure of the trout NALT significantly changed in infected fish, as both the width of the LP and goblet cell density in the lamellae significantly increased in the challenged groups. Similar results have been reported in human $\mathrm{OO}$, within which the colonization of microbes could induce the accumulation of immune cells known to cause morphological changes in the $\mathrm{OO}$ of chronic rhinosinusitis (CRS) patients (26). All of these findings demonstrated that $F$. columnare successfully invaded the trout $\mathrm{OO}$, after which the transcription levels of 15 immune-related genes were detected to evaluate the innate immune responses in the trout OO. These analyses demonstrated that 4 immune genes including CATH-1, IL-10, heat shock proteins, and NOS2 were all significantly upregulated in the OO during early infection. Particularly, cathelicidins contribute substantially to host defense and function as effector molecules of the host innate immune system during bacterial infection $(27,28)$. These peptides were also upregulated in the nasal mucosa and sinonasal mucosa of chronic rhinosinusitis (CRS) patients, who may suffer from multiple etiologies (e.g., allergen, bacterial, viral, or fungal exposure) $(29,30)$. Interleukin-10 (IL-10) is a cytokine with anti-inflammatory properties that limits the immune response to pathogens, thereby preventing damage to the host (31). Additionally, heat shock proteins are not only involved in pro-inflammatory responses but also anti-inflammatory responses (32). NOS-2 mRNA transcription 


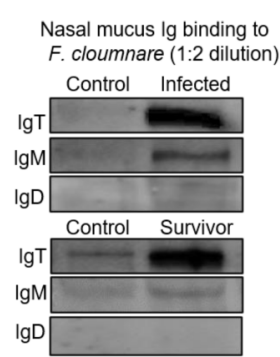

D $\begin{gathered}\text { Serum Ig binding to } \\ \text { F. cloumnare (1:10 dilution) }\end{gathered}$

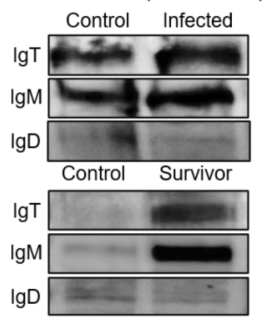

B

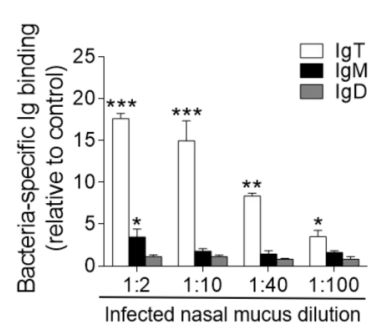

E

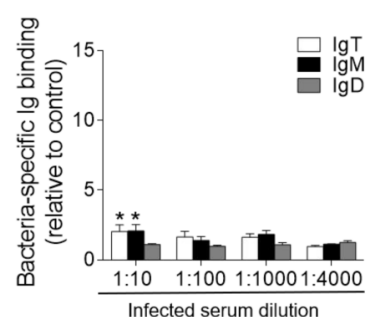

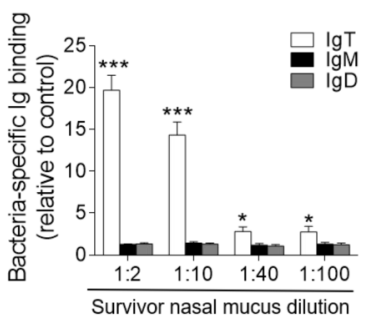

$\mathbf{F}$

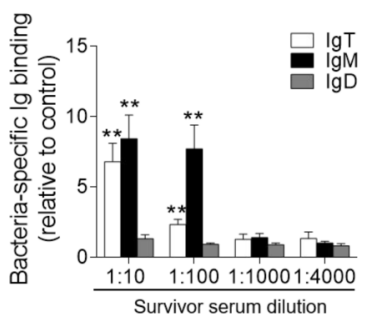

FIGURE 4 | Immunoglobulin responses in the olfactory organ and serum from infected and survivor trout. (A) Western blot analysis of IgT-, IgM-, and IgD- specific binding to $F$. columnare in nasal mucus (dilution 1:2) from infected and survivor fish. (B, C) IgT-, IgM-, and IgD- specific binding to F. columnare in dilutions of nasal mucus from infected $\mathbf{( B )}$ and survivor fish $\mathbf{( C )}$, evaluated by densitometric analysis of immunoblots and presented as relative values to those of control fish $(n=12$ per group). (D) Western blot analysis of IgT-, IgM-, and lgD- specific binding to F. columnare in serum (dilution 1:10) from infected and survivor fish. (E, F) IgT-, IgM-, and IgD- specific binding to $F$. columnare in dilutions of serum from infected (E) and survivor (F) fish, evaluated by densitometric analysis of immunoblots and presented as relative values to those of control fish ( $n=12$ per group). ${ }^{\star} p<0.05,{ }^{\star *} p<0.01$, ${ }^{\star \star \star} p<0.001$ (unpaired Student $t$ test). Data are representative of three independent experiments (mean \pm SEM).

level could be activated within $2-4 \mathrm{~h}$ upon LPS-mediated activation of the innate immune pattern recognition receptors (33). Together, our results described the inflammatory responses in trout $\mathrm{OO}$ after F. columnare infection. Anti-inflammatory and anti-bacterial genes were upregulated in response to $F$. columnare infection, suggesting a tissue repair response. The inflammatory responses of the trout OO increased during F. columnare infection; however, the $\mathrm{OO}$ also protect itself by limiting the duration of this inflammatory response.

F. columnare infection could not only quickly induce a strong innate immune response in the trout $\mathrm{OO}$, but also elicited a longterm adaptive immune response. The mammalian secretory IgA (sIgA) is responsible for the host's nasal mucosa local defense against bacterial pathogens $(15,34)$. Given that much higher proportions of $\operatorname{IgT}^{+} \mathrm{B}$ cells than $\operatorname{IgM}^{+} \mathrm{B}$ cells were observed in the trout $\mathrm{OO}(4)$ and that, similar to the mammalian $\operatorname{IgA}$, IgT is a specialized mucosal Ig isotype against parasitic infection in the gut, gills, and skin of rainbow trout $(7,9,35)$, we hypothesized that IgT may also play a key role in teleost NALT against bacterial infection. In order to identify the role of IgT in teleost NALT during bacterial infection, our study was the first to evaluate the immune responses of three Ig isotypes in teleost NALT. The total IgT concentration increased significantly in the nasal mucus of both the infected and surviving fish after $F$. columnare infection, which was consistent with the increased accumulation of $\operatorname{IgT}^{+} \mathrm{B}$ cells in NALT. Furthermore, the total concentration of another two Igs (IgM and IgD) also increased significantly in nasal mucus after $F$. columnare infection. However, these results are not fully consistent with a previous study, which detected an increased IgT concentration in nasal mucus after parasitic infection, whereas no changes were observed in IgM or IgD concentrations (13). It can be speculated that the differential immune responses of teleost Igs may vary depending on different invading pathogen species. A previous study in humans also detected increased levels of sIgD in nasal tissues but not serum in chronic rhinosinusitis patients after bacterial infection (36). Our study showed that both the protein levels and mRNA expression of IgD significantly increased in nasal mucus after bacterial challenge, whereas serum IgD concentrations exhibited no change, indicating the role of nasal mucosa IgD in the immune responses against $F$. columnare infection. Interestingly, we found differences between protein levels and mRNA expression especially at $28 \mathrm{dpi}$ (i.e., IgT protein levels increased significantly, whereas mRNA expression remained unaltered), which may be due to differences in the mechanisms of action of proteins and mRNA.

We also found that the concentration of IgM in the nasal mucus of infected fish was $\sim 50$-fold higher compared to that of $\operatorname{Ig} \mathrm{T}$, whereas the number of $\operatorname{IgT}^{+} \mathrm{B}$ cells was $\sim 12$-fold higher than that of $\operatorname{IgM}^{+} \mathrm{B}$ cells in the same fish group. These differences in IgT and IgM concentrations have been observed in all mucosal sites analyzed thus far $(7,9,13)$. Moreover, these differences occur not only in mucosal sites but also in serum, where IgM concentrations are $~ 500-1000$ fold higher than those of IgT, whereas the percentage of $\operatorname{IgM}^{+} \mathrm{B}$ cells in systemic lymphoid 
A

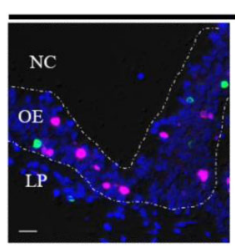

B
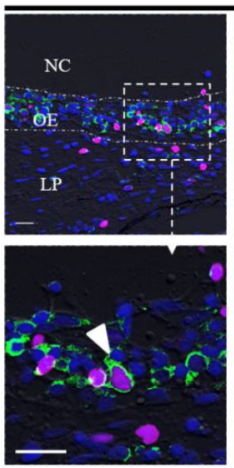

Control

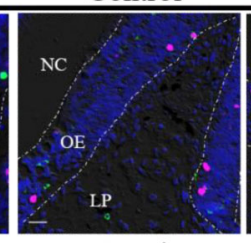

Survivor
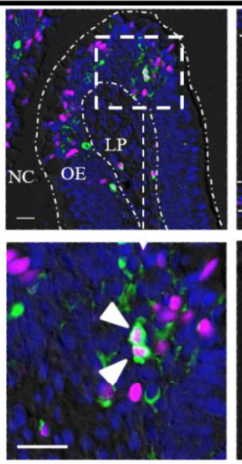
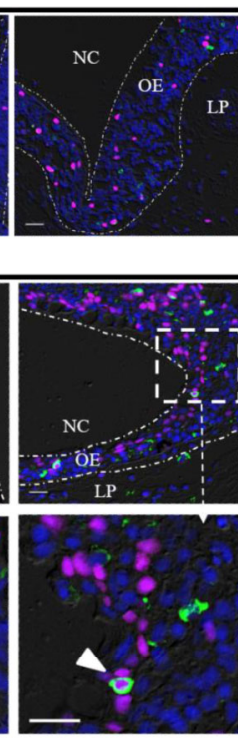

EDU IgT IgM Nucle
C

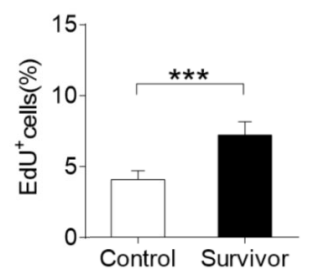

D

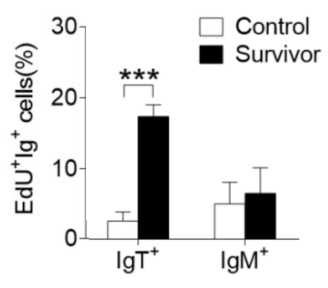

FIGURE 5 | Proliferation of $\operatorname{lgT}^{+}$B cells in the olfactory organ from survivor fish. (A, B) Immunofluorescence analysis of 5-ethynyl-2'-deoxyuridine (EdU) incorporation by $\lg \mathrm{T}^{+}$or $\operatorname{lgM}^{+} \mathrm{B}$ cells in the olfactory organ of control (A) and survivor fish (B) and enlarged images of the areas outlined. Paraffinic sections of olfactory organ were stained for EdU (magenta), trout IgT (green), trout IgM (red), and nuclei (blue) detection. White arrowheads point to cells double stained for EdU and IgT. NC, nasal cavity; OE, olfactory epithelium; LP, lamina propria. Scale bars, $20 \mu \mathrm{m}$. (C) Percentage of EdU ${ }^{+}$cells from total olfactory organ cells in control and survivor fish counted from A and B ( $n=6$ fish per group). We have counted 18 fields or 19 fields in the control or survivor group, respectively. (D) Percentage of EdU ${ }^{+}$cells from the total olfactory organ $\lg \mathrm{T}^{+}$and $\operatorname{lgM}^{+} \mathrm{B}$ cell populations in control and survivor fish, statistically calculated from $\mathrm{A}$ and $\mathrm{B}$. ${ }^{\star \star \star} p<0.001$ (unpaired Student $t$ test). Data in (C, D) are representative of at least three independent experiments (mean \pm SEM).

A

Nose medium Ig binding to

F. cloumnare (1:2 dilution)

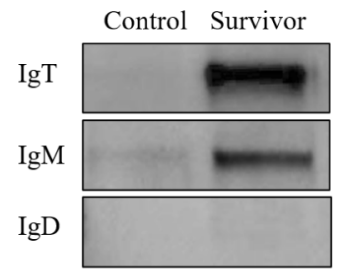

\section{B}

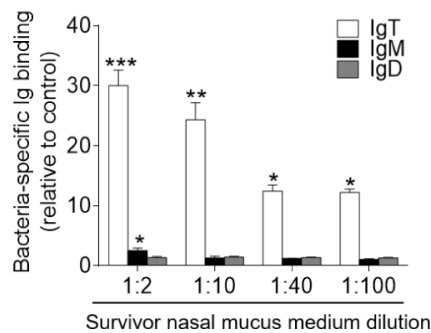

FIGURE 6 | Local IgT-, IgM-, and IgD-specific responses in olfactory organ explants of survivor fish. (A) The olfactory organ explants from control and survivor fish were cultured in medium $(400 \mu l)$ for 7 days. Western blot analysis of $\operatorname{lgT}-$, IgM-, and IgD-specific binding to $F$. columnare in the olfactory organ culture medium (dilution 1:2) from control and survivor fish. (B) IgT-, IgM-, and lgD-specific binding to $F$. columnare in dilutions of olfactory organ culture medium from control and survivor fish, evaluated by densitometric analysis of immunoblots and presented as relative values to those of control fish $\left(n=12\right.$ per group). ${ }^{*} p<0.05,{ }^{* *} p<0.01$, ${ }^{\star \star \star} p<0.001$ (unpaired Student's $t$-test). Data are representative of at least three independent experiments (mean \pm SEM).

organs is only $\sim 3-4$ fold higher than that of $\operatorname{IgT}^{+} \mathrm{B}$ cells. These data indicate that there must be differences in the Ig-secreting capacity of $\operatorname{IgM}^{+}$and $\operatorname{IgT}^{+} \mathrm{B}$ cells. However, the mechanisms responsible for these variations in Ig-secreting capacities remain largely unknown and therefore should be analyzed in future studies. Interestingly, this phenomenon has also been reported in mammals. For example, the average Ig production by $\operatorname{IgA}^{+} \mathrm{B}$ cells is significantly different from that of $\operatorname{IgM}^{+}$and $\operatorname{IgG}^{+} \mathrm{B}$ cells (37). Another possibility that would only apply to mucosal sites is that nasal mucus could have been contaminated with blood during sampling, and therefore we cannot exclude the possibility that the IgM in the nasal mucus derived from blood contamination (i.e., due to potential microhemorrhages that may have occurred during sampling). 
Moreover, although the total protein levels of three Ig classes in nasal mucus all increased after $F$. columnare challenge, except for that of bacteria-specific IgM binding could be detected in up to $1 / 2$ nasal mucus dilution in the infected fish, only bacteria-specific IgT titers were detected in the nasal mucus of both the infected and survivor groups. These results were consistent with previous studies in humans in which specific IgA antibodies were detected in nasal mucosa following infection or nasal vaccination, thereby providing protection against Streptococcus pneumoniae infection or colonization $(15,38)$. Although bacteria-specific $\operatorname{IgM}$ and $\operatorname{IgD}$ levels remained unaltered upon infection, we speculated that increases in total $\operatorname{IgM}$ and $\operatorname{IgD}$ protein may contribute to the binding of microbes in the $\mathrm{OO}$ surface, thereby preventing pathogen invasion. Particularly, F. columnare invaded the trout $\mathrm{OO}$, which may have resulted in the colonization of opportunistic pathogens. Importantly, strong IgT and IgM immune responses were detected in teleost serum both at total protein levels and antigen-specific titers after $F$. columnare infection, which was similar to a study in humans that detected increases in antigenspecific IgA and IgG titers in serum after intranasal viral infection (39). These data suggest that IgT may not only function as the main dedicated Ig isotype in nasal immunity but also contributes to systemic immunity during bacterial infection; however, this phenomenon must be further characterized in future studies.

F. columnare infection increased the accumulation of $\operatorname{IgT}^{+} \mathrm{B}$ in trout NALT. However, their origin remains unknown, as they may have been generated locally or transported to the infection site by systemic lymphoid organs. In mammals, most increases in nasal IgA result from the proliferation of local IgA-producing plasma cells in nasal mucosa from patients with chronic inflammation (40). In vivo proliferation assays have demonstrated that the percentage of proliferative $\operatorname{IgT}^{+} \mathrm{B}$ cells also increased significantly in the surviving fish compared to the control fish, indicating that the accumulated $\operatorname{IgT}^{+} \mathrm{B}$ cells in the nasal mucosa may originate from local proliferation. Furthermore, we also detected high bacteria-specific IgT titers in cultured nasal explants from the surviving fish, which further indicated that the bacteria-specific IgT responses in the OOs could be induced locally during bacterial infection, which was consistent with our previous studies in trout gill and pharyngeal tissues during parasitic infection $(9,24)$. Overall, our data confirmed that trout NALT is a mucosal inductive for IgT responses, which was similar to the mammalian NALT, where $\operatorname{IgA}^{+} \mathrm{B}$ cells were induced/expanded and antigen-specific IgA responses were detected following intranasal viral infection (41). Therefore, our results suggest the convergent role of nasal B cells and nasal Ig responses both in tetrapods and non-tetrapods.

In conclusion, our study was the first to explore the Igs specific immune responses of teleost NALTs during bacterial infection. Upon F. columnare infection, histopathological changes and innate immune responses were detected in trout NALT, and $\mathrm{IgT}^{+} \mathrm{B}$ cells were induced and expanded in NALT, which corresponded with increases in bacteria-specific $\operatorname{IgT}$ responses in trout NALT and serum. Taken together, our results highlighted IgT as a crucial Ig isotype in trout nasal surface immunity, which may also contribute to systemic immunity. Therefore, our study provides new insights into the nasal adaptive immune responses to bacterial infection and contributes to understand the role of fish NALTs during immersion vaccines.

\section{DATA AVAILABILITY STATEMENT}

The datasets presented in this study can be found in online repositories. The names of the repository/repositories and accession number(s) can be found in the article/Supplementary Material.

\section{ETHICS STATEMENT}

The animal study was reviewed and approved by Animal procedures were approved by the Animal Experiment Committee of Huazhong Agricultural University.

\section{AUTHOR CONTRIBUTIONS}

FD and G-mY performed most of the experiments, contributed to the infection model and wrote the manuscript. K-fM contributed to western blot analysis. H-yX and XL performed the immunofluorescence analysis. ZX and Q-cW designed the experiments and revised the manuscript. All authors reviewed the manuscript. All authors contributed to the article and approved the submitted version.

\section{FUNDING}

This work was supported by grants from the National Natural Science Foundation of China (U1905204, 31873045).

\section{ACKNOWLEDGMENTS}

We thank Dr. J. Oriol Sunyer (University of Pennsylvania) for providing the antibodies, including anti-trout IgT mAbs, antitrout $\operatorname{IgM}$, anti-trout $\operatorname{IgD}$, anti-trout $\operatorname{IgT}$ and anti-trout $\mathrm{pIgR}$ pAbs, and Dr. Pin Nie for providing the GFP-expressing Flavobacterium columnare $\mathrm{G}_{4}$.

\section{SUPPLEMENTARY MATERIAL}

The Supplementary Material for this article can be found online at: https://www.frontiersin.org/articles/10.3389/fimmu.2020. 583740/full\#supplementary-material 


\section{REFERENCES}

1. Sepahi A, Salinas I. The evolution of nasal immune systems in vertebrates. Mol Immunol (2016) 69:131-8. doi: 10.1016/j.molimm.2015.09.008

2. Agbesi MP, Naylor S, Perkins E, Borsuk HS, Sykes D, Maclaine JS, et al. Complex flow in the nasal region of guitarfishes. Comp Biochem Physiol A Mol Integr Physiol (2016) 193:52-63. doi: 10.1016/j.cbpa.2015.12.007

3. Kuper CF, Koornstra PJ, Hameleers DM, Biewenga J, Spit BJ, Duijvestijn AM, et al. The role of nasopharyngeal lymphoid tissue. Immunol Today (1992) 13 (6):219-24. doi: 10.1016/0167-5699(92)90158-4

4. Tacchi L, Musharrafieh R, Larragoite ET, Crossey K, Erhardt EB, Martin SAM, et al. Nasal immunity is an ancient arm of the mucosal immune system of vertebrates. Nat Commun (2014) 5:5205. doi: 10.1038/ncomms6205

5. Liang B, Hyland L, Hou S. Nasal-associated lymphoid tissue is a site of longterm virus-specific antibody production following respiratory virus infection of mice. J Virol (2001) 75(11):5416-20. doi: 10.1128/jvi.75.11.5416-5420.2001

6. Salinas I, Zhang YA, Sunyer JO. Mucosal immunoglobulins and B cells of teleost fish. Dev Comp Immunol (2011) 35(12):1346-65. doi: 10.1016/j.dci.2011.11.009

7. Zhang YA, Salinas I, Li J, Parra D, Bjork S, Xu Z, et al. IgT, a primitive immunoglobulin class specialized in mucosal immunity. Nat Immunol (2010) 11(9):827-35. doi: 10.1038/ni.1913

8. Ramirez-Gomez F, Greene W, Rego K, Hansen JD, Costa G, Kataria P, et al. Discovery and characterization of secretory $\operatorname{IgD}$ in rainbow trout: secretory IgD is produced through a novel splicing mechanism. J Immunol (2012) 188 (3):1341-9. doi: 10.4049/jimmunol.1101938

9. Xu Z, Takizawa F, Parra D, Gomez D, von Gersdorff Jorgensen L, LaPatra SE, et al. Mucosal immunoglobulins at respiratory surfaces mark an ancient association that predates the emergence of tetrapods. Nat Commun (2016) 7:10728. doi: 10.1038/ncomms10728

10. Yu YY, Kong WG, Xu HY, Huang ZY, Zhang XT, Ding LG, et al. Convergent Evolution of Mucosal Immune Responses at the Buccal Cavity of Teleost Fish. iScience (2019) 19:821-35. doi: 10.1016/j.isci.2019.08.034

11. Hansen JD, Landis ED, Phillips RB. Discovery of a unique Ig heavy-chain isotype $(\operatorname{IgT})$ in rainbow trout: Implications for a distinctive B cell developmental pathway in teleost fish. Proc Natl Acad Sci USA (2005) 102 (19):6919-24. doi: 10.1073/pnas.0500027102

12. Danilova N, Bussmann J, Jekosch K, Steiner LA. The immunoglobulin heavychain locus in zebrafish: identification and expression of a previously unknown isotype, immunoglobulin Z. Nat Immunol (2005) 6(3):295-302. doi: $10.1038 /$ ni1 166

13. Yu YY, Kong W, Yin YX, Dong F, Huang ZY, Yin GM, et al. Mucosal immunoglobulins protect the olfactory organ of teleost fish against parasitic infection. PloS Pathog (2018) 14(11):e1007251. doi: 10.1371/journal.ppat.1007251

14. Wright AK, Ferreira DM, Gritzfeld JF, Wright AD, Armitage K, Jambo KC, et al. Human nasal challenge with Streptococcus pneumoniae is immunising in the absence of carriage. PloS Pathog (2012) 8(4):e1002622. doi: 10.1371/ journal.ppat.1002622

15. Richards L, Ferreira DM, Miyaji EN, Andrew PW, Kadioglu A. The immunising effect of pneumococcal nasopharyngeal colonisation; protection against future colonisation and fatal invasive disease. Immunobiology (2010) 215(4):251-63. doi: 10.1016/j.imbio.2009.12.004

16. Tripathi NK, Latimer KS, Gregory CR, Ritchie BW, Wooley RE, Walker RL. Development and evaluation of an experimental model of cutaneous columnaris disease in koi Cyprinus carpio. J Vet Diagn Invest (2005) 17 (1):45-54. doi: 10.1177/104063870501700109

17. Suomalainen LR, Bandilla M, Valtonen ET. Immunostimulants in prevention of columnaris disease of rainbow trout, Oncorhynchus mykiss (Walbaum). J Fish Dis (2009) 32(8):723-6. doi: 10.1111/j.1365-2761.2009.01026.x

18. Declercq AM, Chiers K, Haesebrouck F, Van den Broeck W, Dewulf J, Cornelissen $\mathrm{M}$, et al. Gill infection model for columnaris disease in common carp and rainbow trout. J Aquat Anim Health (2015) 27(1):1-11. doi: $10.1080 / 08997659.2014 .953265$

19. Scott SJ, Bollinger TK. Flavobacterium columnare: an important contributing factor to fish die-offs in southern lakes of Saskatchewan, Canada. J Vet Diagn Invest (2014) 26(6):832-6. doi: 10.1177/1040638714553591

20. Declercq AM, Haesebrouck F, Van den Broeck W, Bossier P, Decostere A. Columnaris disease in fish: a review with emphasis on bacterium-host interactions. Vet Res (2013) 44(1):27. doi: 10.1186/1297-9716-44-27
21. Li N, Zhu Y, LaFrentz BR, Evenhuis JP, Hunnicutt DW, Conrad RA, et al. The Type IX Secretion System Is Required for Virulence of the Fish Pathogen Flavobacterium columnare. Appl Environ Microbiol (2017) 83(23):e0176901717. doi: 10.1128/aem.01769-17

22. Pfaffl MW. A new mathematical model for relative quantification in real-time RT-PCR. Nucleic Acids Res (2001) 29(9):e45. doi: 10.1093/nar/29.9.e45

23. Bader JA, Shoemaker CA, Klesius PH. Rapid detection of columnaris disease in channel catfish (Ictalurus punctatus) with a new species-specific 16-S rRNA gene-based PCR primer for Flavobacterium columnare. J Microbiol Methods (2003) 52(2):209-20. doi: 10.1016/s0167-7012(02)00208-7

24. Kong WG, Yu YY, Dong S, Huang ZY, Ding LG, Cao JF, et al. Pharyngeal Immunity in Early Vertebrates Provides Functional and Evolutionary Insight into Mucosal Homeostasis. J Immunol (2019) 203(11):3054-67. doi: 10.4049/ jimmunol.1900863

25. Salic A, Mitchison TJ. A chemical method for fast and sensitive detection of DNA synthesis in vivo. Proc Natl Acad Sci USA (2008) 105(7):2415-20. doi: $10.1073 /$ pnas.0712168105

26. Stevens WW, Schleimer RP, Kern RC. Chronic Rhinosinusitis with Nasal Polyps. J Allergy Clin Immunol Pract (2016) 4(4):565-72. doi: 10.1016/j.jaip.2016.04.012

27. Chen Y, Cai S, Qiao X, Wu M, Guo Z, Wang R, et al. As-CATH1-6, novel cathelicidins with potent antimicrobial and immunomodulatory properties from Alligator sinensis, play pivotal roles in host antimicrobial immune responses. Biochem J (2017) 474(16):2861-85. doi: 10.1042/bcj20170334

28. Wong JH, Ye XJ, Ng TB. Cathelicidins: peptides with antimicrobial, immunomodulatory, anti-inflammatory, angiogenic, anticancer and procancer activities. Curr Protein Pept Sci (2013) 14(6):504-14. doi: 10.2174/ 13892037113149990067

29. Ooi EH, Wormald PJ, Carney AS, James CL, Tan LW. Human cathelicidin antimicrobial peptide is up-regulated in the eosinophilic mucus subgroup of chronic rhinosinusitis patients. Am J Rhinol (2007) 21(4):395-401. doi: 10.2500/ajr.2007.21.3048

30. Thienhaus ML, Wohlers J, Podschun R, Hedderich J, Ambrosch P, Laudien M. Antimicrobial peptides in nasal secretion and mucosa with respect to Staphylococcus aureus colonization in chronic rhinosinusitis with nasal polyps. Rhinology (2011) 49(5):554-61. doi: 10.4193/Rhino10.072

31. Iyer SS, Cheng G. Role of interleukin 10 transcriptional regulation in inflammation and autoimmune disease. Crit Rev Immunol (2012) 32(1):2363. doi: 10.1615/critrevimmunol.v32.i1.30

32. Zininga T, Ramatsui L, Shonhai A. Heat Shock Proteins as Immunomodulants. Molecules (2018) 23(11):2846. doi: 10.3390/molecules23112846

33. Lowenstein CJ, Padalko E. iNOS (NOS2) at a glance. J Cell Sci (2004) 117 (14):2865-7. doi: 10.1242/jcs.01166

34. Sun K, Johansen FE, Eckmann L, Metzger DW. An important role for polymeric Ig receptor-mediated transport of IgA in protection against Streptococcus pneumoniae nasopharyngeal carriage. J Immunol (2004) 173 (7):4576-81. doi: 10.4049/jimmunol.173.7.4576

35. Xu Z, Parra D, Gómez D, Salinas I, Zhang YA, von Gersdorff Jørgensen L, et al. Teleost skin, an ancient mucosal surface that elicits gut-like immune responses. Proc Natl Acad Sci USA (2013) 110(32):13097-102. doi: 10.1073/pnas.1304319110

36. Min JY, Nayak JV, Hulse KE, Stevens WW, Raju PA, Huang JH, et al. Evidence for altered levels of $\mathrm{IgD}$ in the nasal airway mucosa of patients with chronic rhinosinusitis. J Allergy Clin Immunol (2017) 140(6):15621571.e1565. doi: 10.1016/j.jaci.2017.05.032

37. Gitlin D, Sasaki T. Immunoglobulins G, A, and M Determined in Single Cells from Human Tonsil. Science (1969) 164(3887):1532. doi: 10.1126/science.164.3887.1532

38. Fukuyama Y, King JD, Kataoka K, Kobayashi R, Gilbert RS, Oishi K, et al. Secretory-IgA antibodies play an important role in the immunity to Streptococcus pneumoniae. J Immunol (2010) 185(3):1755-62. doi: 10.4049/ jimmunol.1000831

39. Gould VMW, Francis JN, Anderson KJ, Georges B, Cope AV, Tregoning JS. Nasal IgA Provides Protection against Human Influenza Challenge in Volunteers with Low Serum Influenza Antibody Titre. Front Microbiol (2017) 8:900. doi: 10.3389/fmicb.2017.00900

40. Nakashima T, Hamashima Y. Local immune system of nasal nucosa in inflammation. IgA distribution and secretory activity. Ann Otol Rhinol Laryngol (1980) 89(2 Pt 1):140-6. doi: 10.1177/000348948008900210

41. Zuercher AW, Coffin SE, Thurnheer MC, Fundova P, Cebra JJ. Nasalassociated lymphoid tissue is a mucosal inductive site for virus-specific 
humoral and cellular immune responses. J Immunol (2002) 168(4):1796-803. doi: 10.4049/jimmunol.168.4.1796

Conflict of Interest: The authors declare that the research was conducted in the absence of any commercial or financial relationships that could be construed as a potential conflict of interest.
Copyright $\odot 2020$ Dong, Yin, Meng, Xu, Liu, Wang and Xu. This is an open-access article distributed under the terms of the Creative Commons Attribution License (CC BY). The use, distribution or reproduction in other forums is permitted, provided the original author(s) and the copyright owner(s) are credited and that the original publication in this journal is cited, in accordance with accepted academic practice. No use, distribution or reproduction is permitted which does not comply with these terms. 